\section{FRI0355 MUCOSAL ASSOCIATED INVARIANT T-CELLS ARE ENRICHED AT THE HUMAN ENTHESIS AND HAVE A RESIDENT MEMORY PHENOTYPE}

Richard Cuthbert ${ }^{1}$, Qiao Zhou ${ }^{1}$, Abdulla Watad ${ }^{1}$, Robert Dunsmuir ${ }^{2}$, Peter Loughenbury ${ }^{2}$, Almas Khan ${ }^{2}$, Peter Millner ${ }^{2}$, Charlie Bridgewood ${ }^{1}$, Dennis Mcgonagle'. ' University of Leeds, Leeds Institute of Rheumatic and Musculoskeletal Medicine, Leeds, United Kingdom; ${ }^{2}$ Leeds General Infirmary, Spinal Surgery, Leeds, United Kingdom

Background: Mucosal associated invariant T-cells (MAITs) are innate-like $T$ lymphocytes that express a semi-invariant TCR repertoire. They are activated by microbial ligands or cytokines including IL-23 and secrete inflammatory cytokines, including IFN $\gamma$ and IL-17A. MAIT cells are enriched at mucosal surfaces and have been implicated in the pathogenesis of spondyloarthritis (SpA) (1) and inflammatory bowel disease (IBD). Although the human enthesis is not a mucosal surface it is the primary site of inflammation in SpA which has strong association with IBD.

Objectives: To investigate if a population of MAITs is present at the normal human enthesis thereby establishing a potential link between gut and joint inflammation.

Methods: Healthy interspinous ligament and spinous process were harvested from patients undergoing elective surgery for the correction of mechanical spinal defects. Entheseal soft tissue (EST) and peri-entheseal bone (PEB) were separated and cells were harvested by enzymatic and mechanical digestion respectively. The proportion of cells expressing markers consistent with MAITS (CD45+, CD3+, CD161+, TCRV $\alpha 7.2+$ ) were measured by flow cytometry in EST, PEB and matched blood. Expression of CD69 and CD45RA were examined for phenotypic analysis. Transcript analysis for IL-23/L-17 axis and immunomodulatory genes was performed on sorted entheseal MAITs and analysed by TaqMan array. Results: As a proportion of total T-cells, MAITs were of approximately 3 fold and 2.5 fold greater abundance in EST and PEB respectively in comparison to matched peripheral blood (both $p=0.034$ ). MAITs in entheseal tissue had an overwhelming resident memory phenotype (CD69+, CD45RA-) median $53.2 \%$ (range $42.4-78.6 \%$ ) in EST and $54.9 \%(45.2$ - 82.1\%) in PEB compared to those from blood 17.7 (6.8 - 69.4). MAITs robustly expressed RORC, CCR6 and IL-23R transcript. Compared to conventional entheseal T-cells, MAITs expressed significantly less TGF $\beta$ (6-fold, $p>0.001$ ) and significantly more IL-23R (29-fold, $p=0.004$ ).

Conclusion: Healthy human entheseal tissue contains an enriched population of MAITs that strongly express IL-23R transcript at a frequency comparable to that reported in the colon (2). The majority of these cells express a resident memory phenotype suggesting that they are a distinct population residing in entheseal tissue. These observations are potentially relevant to SpA pathogenesis and the observed link between SpA and IBD.

\section{REFERENCES:}

[1] Gracey E, Qaiyum Z, Almaghlouth I, Lawson D, Karki S, Avvaru N, et al. IL-7 primes IL-17 in mucosal-associated invariant T (MAIT) cells, which contribute to the Th17-axis in ankylosing spondylitis. Annals of the rheumatic diseases. 2016:annrheumdis-2015-208902.

[2] Salou M, Franciszkiewicz K, Lantz O. MAIT cells in infectious diseases. Current opinion in immunology. 2017;48:7-14.

Disclosure of Interests: Richard Cuthbert: None declared, Qiao Zhou: None declared, Abdulla Watad: None declared, Robert Dunsmuir: None declared, Peter Loughenbury: None declared, Almas Khan: None declared, Peter Millner: None declared, Charlie Bridgewood: None declared, Dennis McGonagle Consultant for: Lilly, Novartis UCB, Speakers bureau: Lilly, Novartis UCB

DOI: 10.1136/annrheumdis-2019-eular.7314

\section{FRI0356 DIFFERENTIAL EXPRESSION OF HUMAN} ENDOGENOUS RETROVIRUSES IN PSORIATIC DISEASE

Remy Pollock ${ }^{1}$, Rohan Machhar ${ }^{1}$, Laila Zaman ${ }^{1}$, Dafna D. Gladman ${ }^{1,2}$, Vinod Chandran ${ }^{1,2,3,4} .{ }^{1}$ Krembil Research Institute, University Health Network, Psoriatic Disease Research Program, Toronto, Canada; ${ }^{2}$ Faculty of Medicine, University of Toronto, Division of Rheumatology, Toronto, Canada; ${ }^{3}$ University of Toronto, Department of Laboratory Medicine and Pathobiology, Toronto, Canada; ${ }^{4}$ Memorial University, Faculty of Medicine, St. John's, Canada

Background: Human endogenous retroviruses (HERV) are the stably inherited remnants of ancient retroviruses that infected the ancestral germline. A growing body of research has associated the differential expression and regulation of HERVs with a number of diseases, including systemic lupus erythematosus (SLE) and rheumatoid arthritis (RA). HERVs are thought to contribute to the pathogenesis of autoimmune diseases by modulating the expression of host immune-related genes, molecular mimicry, or cross reactivity of host proteins with HERV encoded products. Objectives: To compare the expression of $4 \mathrm{HERVs}$ previously associated with autoimmune disorders (HERV-K, HERV-K10, HERV-W, and HERV-H) in whole blood, CD3+ T cells, and CD14+ monocytes of patients with cutaneous psoriasis without arthritis (PsC), psoriatic arthritis (PsA), and healthy controls.

Methods: PsC, PsA patients satisfying the CASPAR criteria, and healthy controls were recruited for the study. RNA was extracted from whole blood collected in Tempus tubes and HERV expression was measured by quantitative real time PCR (qRT-PCR) or droplet digital (dd)PCR with normalization to GAPDH. HERV expression in whole blood RNA from 40 PsA patients was compared to 40 age and sex matched PsC patients and 40 age and sex matched healthy controls. Subsequently, HERV expression in 55 PsC patients who progressed to develop PsA (converters) was compared to 55 age and sex matched PsC patients who did not develop PsA over the same duration of follow-up (non-converters). Finally, HERV expression in RNA isolated from CD3+ T cells and CD14+ monocytes from 19 PsA patients was compared to 13 PsC and 8 healthy controls. Expression differences between groups were determined by one-way ANOVA, Kruskal-Wallis and Mann-Whitney tests where appropriate.

Results: In whole blood, HERV-K was significantly differentially expressed between 40 PsA and 40 PsC patients (fold change $[F C]=1.57, p=0.008$ ). HERV-K was also significantly differentially expressed in baseline samples from 55 converters compared to 55 non-converters ( $F C=1.93, p=0.03)$. No other HERV genes were differentially expressed between these groups in whole blood. Significant expression differences were more evident in purified cells (Table 1).

Table 1. Differential expression of HERVs in purified T cells and monocytes.

\begin{tabular}{|c|c|c|c|c|c|c|}
\hline & \multicolumn{2}{|c|}{ PsA vs. PsC } & \multicolumn{2}{|c|}{ PsA vs. Controls } & \multicolumn{2}{|c|}{ PsC vs. Controls } \\
\hline & $\begin{array}{l}\text { CD3+ T } \\
\text { cells } \\
\text { FC, } p \\
\text { value }\end{array}$ & $\begin{array}{c}\text { CD14+ } \\
\text { Monocytes } \\
\text { FC, p value }\end{array}$ & $\begin{array}{c}\text { CD3+ T } \\
\text { cells } \\
\text { FC, } p \\
\text { value }\end{array}$ & $\begin{array}{c}\text { CD14+ } \\
\text { Monocytes } \\
\text { FC, p value }\end{array}$ & $\begin{array}{c}\text { CD3+ T } \\
\text { cells } \\
\text { FC, } p \\
\text { value }\end{array}$ & $\begin{array}{c}\text { CD14+ } \\
\text { Monocytes } \\
\text { FC, p value }\end{array}$ \\
\hline HERV-K & $\begin{array}{c}0.43 \\
p=0.02\end{array}$ & $0.30, p<0.01$ & ns & $0.17, p<0.01$ & $\begin{array}{c}2.18 \\
p=0.02\end{array}$ & ns \\
\hline $\begin{array}{l}\text { HERV- } \\
\text { K10 }\end{array}$ & $\begin{array}{c}2.94 \\
p=0.02\end{array}$ & ns & $\begin{array}{c}6.87 \\
p<0.01\end{array}$ & $2.60, p=0.04$ & ns & ns \\
\hline $\begin{array}{l}\text { HERV- } \\
\mathrm{H}\end{array}$ & ns & ns & $\begin{array}{c}3.19 \\
p<0.01\end{array}$ & $0.36, p=0.02$ & $\begin{array}{c}2.67 \\
p=0.01\end{array}$ & $0.27, p<0.01$ \\
\hline $\begin{array}{l}\text { HERV- } \\
W \\
\text { W }\end{array}$ & $\begin{array}{c}1.27 \\
p=0.04\end{array}$ & ns & $\begin{array}{c}4.12 \\
p<0.01\end{array}$ & ns & $\begin{array}{c}3.24 \\
p=0.01\end{array}$ & $0.47, p=0.04$ \\
\hline
\end{tabular}

Ns, not significant.

Conclusion: In whole blood, expression of HERV-K differentiates PsA and PsC patients, and its expression is significantly elevated in PsC patients prior to the development of PsA. HERV expression differences between the groups are also evident in purified $T$ cells and monocytes These data suggest a role for HERVs in the pathogenesis of psoriatic disease and their potential use as prognostic markers of arthritis in patients with psoriasis.

Disclosure of Interests: Remy Pollock: None declared, Rohan Machhar: None declared, Laila Zaman: None declared, Dafna D Gladman Grant research support from: AbbVie, Amgen, Celgene, Lilly, Novartis, Pfizer, and UCB, Consultant for: AbbVie, Amgen, BMS, Celgene, Galapagos Gilead, Janssen, Lilly, Novartis, Pfizer, and UCB, Vinod Chandran: None declared

DOI: 10.1136/annrheumdis-2019-eular.6288

\section{FRI0357 DRUG-INDUCED REMISSION AND SUBCLINICAL ACTIVITY IN PSORIATIC ARTHRITIS: TRANSCRIPTIONAL PROFILING TO CHARACTERIZETHE DISEASE STATE}

Maria Maddalena Angioni, Enrico Mascia, Daniela Perra, Silvia Pinna, Ignazio Cangemi, Piero Mascia, Mattia Congia, Alberto Floris, Matteo Piga, Alessandro Mathieu, Alberto Cauli. Università degli Studi ed AOU di Cagliari, Dip.to Scienze Mediche e Sanita' Pubblica, Unità di Reumatologia, Monserrato (Cagliari), Italy

Background: Remission is an important goal of therapy in psoriatic arthritis (PsA), but data on molecular players of clinical remission and effective 